\title{
Nellore cloned calf viability during the postnatal period
}

\author{
Guilherme Gonçalves Fabretti Santos ${ }^{*}$ (D) Bruno Fornitano Cholfe ${ }^{2}$ \\ Igor Augusto Andreta Paiola ${ }^{3}$ Doão Morelli Júnior ${ }^{3}$ D \\ Eduardo Harry Birgel Junior ${ }^{4}$ (D) Luiz Cláudio Nogueira Mendes $^{5}$ (D) \\ Maria Cecília Rui Luvizotto ${ }^{5}$ (D) Francisco Leydson Formiga Feitosa ${ }^{5}$ (iD
}

\author{
${ }^{1}$ Universidade Paulista (UNIP), 17048-290, Bauru, SP, Brasil. E-mail: guilherme_fabretti@hotmail.com. "Corresponding author. \\ ${ }^{2}$ União das Faculdades dos grandes lagos (UNILAGO), São José do Rio Preto, SPי, Brasil. \\ ${ }^{3}$ Centro Universitário de Rio Preto (UNIRP), São José do Rio Preto, SP, Brasil. \\ ${ }^{4}$ Departamento de Medicina Veterinária, Faculdade de Zootecnia e Engenharia de Alimentos (FZEA) Universidade de São Paulo (USP), \\ Pirassununga, SP, Brasil. \\ ${ }^{5}$ Faculdade de Medicina Veterinária de Araçatuba (FMVA), Universidade Estadual Paulista (UNESP), Araçatuba, SP, Brasil.
}

\begin{abstract}
This study evaluated the viability of Nellore cloned calves derived from somatic cell nuclear transfer (SCNT) and compare their viability with animals of the same breed derived from in vitro fertilization (IVF). Thus, two groups were formed. Group I (GI) consisted of 10 calves derived from SCNT and group II (GII) consisted of 10 calves derived from IVF. The differences detected between the groups were in the physical examination of the respiratory tract in GI, which represented the most common clinical-pathological disturbances. The Apgar index score indicated that $80 \%$ of GI animals were depressed and all had pale mucous membranes. Thus, anemia was reported in GI. In GII, this started at 12 h of life and was probably caused by an iron deficiency. Moreover, total calcium and ionized calcium levels were higher in GI immediately after birth. These alterations probably resulted in a high incidence of mortality in GI, reaching $90 \%$ of the calves, whereas mortality was only $20 \%$ for the calves in GII. In conclusion, cloned calves, which were derived from SCNT, had physiological and metabolic alterations after delivery, leading to a higher mortality rate during the perinatal period.
\end{abstract}

Key words: calves, cloned, clinical, pathology, laboratorial assessment.

Viabilidade de bezerros nelores clonados durante o período pós natal imediato

RESUMO: $O$ objetivo deste trabalho foi avaliar a viabilidade de bezerros da raça Nelore oriundos da técnica da transferência nuclear de células somáticas (TNCS), no período pós natal imediato, comparando-a com animais desta mesma raça, oriundos de fertilização in vitro (FIV). Para tanto, os animais foram alocados em dois grupos, a saber: Grupo I (GI) - 10 animais frutos de TNCS; e, Grupo II (GII) - 10 animais oriundos de FIV. Nos respectivos bezerros, todos obtidos por cesariana, foram realizadas as avaliações fisicas, escore de APGAR, bem como coleta de amostras de sangue nos momentos 0 (ao nascimento), às 2, 4, 6 e 12 horas de vida, a fim de avaliar os resultados de eritrograma, análises bioquímicas e hormonais, comparando-os entre os grupos e momentos. Nos animais que vieram a óbito foi realizada a necropsia para investigar a causa mortis. As diferenças observadas foram em relação aos achados clínico-patológicos, envolvendo, principalmente, o sistema respiratório caracterizado por bradpneia associada à dispneia, e a presença de edema e atelectasia pulmonar observadas no GI. Ademais, após a colostragem notou-se que $80 \%$ dos animais avaliados não foram capazes de manter a glicemia sendo mais evidentes nos animais do GII, possivelmente devido à hiperinsulinemia que se manifestou neste grupo ao longo de todo o periodo experimental. A anemia após o nascimento foi evidente no grupo de bezerros clonados ao longo de todo período de avaliação ao contrário dos bezerros oriundos de GII, a qual foi observada somente às 12 horas de vida, sendo, possivelmente, de origem ferropriva. Casos de hipercalcemia foram denotados nos animais do GI ao nascimento, sendo possivelmente associados à asfixia perinatal. Estas alterações, em conjunto, levaram a uma taxa de mortalidade de $90 \%$ dos animais do GI e de $20 \%$ dos bezerros do GII. Conclui-se que os animais oriundos da TNCS apresentam alterações fisiológicas e metabólicas após o nascimento, responsáveis, em grande parte, pela maior taxa de óbitos dentro do periodo perinatal. Palavras-chave: bezerro, clonagem, clínica, patologia, avaliação laboratoriais.

\section{INTRODUCTION}

Over 25 years ago, somatic cell nuclear transfer (SCNT) produced the first food animal (WILMUT et al., 1997). Bovines are the most successfully cloned species; however, the technique is still associated with neonatal problems, including respiratory failure, fetal oversize, limb flexural deformity, and various congenital defects (CHAVATTE-PALMER et al., 2012).

In Brazil, despite efforts, mortality rates following the birth of cloned calves are still high, at 
approximately $50 \%$. The main complications included respiratory problems and metabolic abnormalities (BIRGEL JÚNIOR et al., 2011).

These situations can be seen in newborns derived from other biotechnical procedures, such as in vitro fertilization (IVF) (FARIN, 2006). Physiological alterations during late pregnancy can lead to clinical disturbances, including increased birth weights. This is followed by reduced vigor and viability at the birth of IVF neonates (HILL, 2014).

Therefore, pregnancy and newborns from these biotechnical procedures remain a medical challenge. A standard protocol based on laboratory data is the key to ensuring neonatal health (BIRGEL JÚNIOR et al., 2011).

This study evaluated the viability of cloned calves derived from SCNT and compared them with animals from the same breed derived from IVF. Our hypothesis was that cloned and IVF calves would develop neonatal complications and require intensive management in a dedicated neonatal intensive care unit.

\section{MATERIALS AND METHODS}

Between 2014 and 2017, at a teaching veterinary hospital, Dr. Halim Atique participated in the birth and the first few days of postpartum care of newborn Nellore calves derived from somatic cloning. The gestation of 20 recipient heifer crossbreeds (Bos taurus $\times$ Bos indicus) was observed. Ten animals conceived Nellore calves derived from SCNT and the other 10 recipients conceived Nellore calves derived from IVF. Thus, two groups were formed. Group I (GI) consisted of the 10 calves derived from SCNT and group II (GII) consisted of the 10 calves derived from IVF. All heifers were housed and fed together throughout gestation with corn silage, mineral salts, and water ad libitum.

All calves were delivered via cesarean sections according to BAIRD (2013). A proximal paravertebral block was performed in the neural branches of T13, L1, and L2 with $5 \mathrm{~mL}$ of lidocaine $2 \%$ (Xylestesin $^{\circledR} 2 \%$; Cristália, Sao Paulo, Brazil) in the ventral and dorsal surfaces of the transversal processes. Briefly, parturition was induced at $285 \mathrm{~d}$ of gestation with an $8 \mathrm{mg}$ intramuscular (i.m.) injection of triamcinolone acetonide (Retardoesteóide, Laboratorio Hertape-Calier Saude Animal, Juatuba, Brazil), and $20 \mathrm{mg}$ i.m. of dexamethasone (Azium; Merck Sharp \& Dohme, Kenilworth, NJ, USA) $24 \mathrm{~h}$ before cesarean delivery (MEIRELLES et al., 2010).

After the exteriorization of the calf, the umbilical cord was clamped to avoid hemorrhage.
The calves were suspended upside down following delivery for less than $90 \mathrm{~s}$ to clean their airways. The Apgar score was determined at birth and 5 min later (FEITOSA \& BENESI, 2014). If the Apgar score did not improve significantly at the second evaluation, an intranasal catheter was placed for $\mathrm{O}_{2}$ supplementation at a rate of $5-7 \mathrm{~L} / \mathrm{min}$. In the case of meconium staining, the calves were immediately cleaned with detergent and warm water to favor drying. Newborns were quickly moved to a warm room and cleaned with towels. At this time, the physical examination was conducted, and laboratory samples were taken. Birth weight was rated and animals heavier than $45 \mathrm{~kg}$ were characterized as having macrosomia (MEIRELLES et al., 2010).

Calves were monitored by repeated blood sampling and determination of temperature, mucous membrane color, and heart and respiratory rates (FEITOSA \& BENESI, 2014) to evaluate neonatal adaptation to life ex utero. Physical examinations were performed immediately after birth, and at 2, 4, 6 , and $12 \mathrm{~h}$ after delivery.

Colostrum was offered in small bottles until the animals received approximately $10 \%$ of their body weight on the first day of life. If the calves did not have a suckling reflex, colostrum at an equivalent volume to $5 \%$ of the calf weight was administered via an esophageal tube within the first $5 \mathrm{~h}$ of life and another 5\% was given until $24 \mathrm{~h}$ after birth. All colostrum was previously frozen and contained 80-140 $\mathrm{mg} / \mathrm{mL}$ immunoglobulin concentration as determined by specific gravity (Colostrometer; Biogenics, Mapleton, OR, USA).

Only the animals that received colostrum by esophageal tube had their blood glucose concentrations evaluated every hour from $5 \mathrm{~h}$ of life using a portable glucometer. If blood glucose fell below $50 \mathrm{mg} / \mathrm{dL}, 0.2 \mathrm{~g} / \mathrm{Kg}$ of glucose was administered intravenously (i.v.) for 50\% supplementation.

Blood samples were collected from the jugular vein in Vacutainer $^{\circledR}$ tubes containing ethylenediaminetetraacetic acid (EDTA; Becton Dickinson, Franklin Lakes, NJ, USA) and subjected to hematological analysis. Total red blood cells (RBC) and hemoglobin were calculated using a semiautomated Urit 3000Plus (Urit Medical Electronics, Shenzhen, China). Hematocrit was determined by centrifugation of microhematocrit tubes at $13.000 \mathrm{~g}$ for $5 \mathrm{~min}$. The RBC indices of mean corpuscular volume and mean corpuscular hemoglobin concentration were calculated using the results from the red fraction (THRALL, 2007). Additional blood was collected in Vacutainer tubes 
containing sodium fluoride to perform insulin, glucose, and lactate analysis. Another blood sample was collected in Vacutainer ${ }^{\circledR}$ tubes with no anticoagulant to access biochemical parameters. All samples were taken to the laboratory and centrifuged. The blood plasma and serum were frozen at $-20{ }^{\circ} \mathrm{C}$ until analysis.

Biochemical assays were performed to evaluate serum total bilirubin, unconjugated bilirubin, conjugated bilirubin, total calcium, iron, plasma glucose, and lactate (Bioclin LTDA, Belo Horizante, Brazil), using the automatic biochemical analyzer, the prietest Touch (Robonik, Thane, India). Ionized calcium was accessed using the ionselective electrode method (Electrolyte Analyzer; Roche Diagnostics, Indianapolis, IN, USA). Plasma insulin was quantified using radioimmuno assays (PerkinElmer, Inc., Waltham, MA, USA).

Animals that died were necropsied at the pathology veterinary service in the hospital. All macroscopic findings from the necropsy were documented, and samples of all tissues were collected for histopathological examination.

A Shapiro-Wilk test was performed to test for normality. Data that were normally distributed were analyzed using a repeated-measures analysis of variance to determine if there were significant differences among moments and groups and Tukey's test was used to compare means. For data that were not normally distributed, the Mann-Whitney test was used to compare groups and moments. The non-paired t-test was used to compare birth weights between the groups. Physical parameters after birth were subjected to Fisher's exact test. Spearman correlation between Apgar scores and lactate levels was performed. A value of $\mathrm{P}<0.05$ was considered significant. The statistical analyses were performed using SAS software (Statistical Analysis System; SAS Institute Inc., Cary, NC, USA) (ZAR, 1999).

\section{RESULTS AND DISCUSSION}

Despite intensive neonatal care, the mortality rates were $90 \%(9 / 10)$ in GI and $20 \%$ $(2 / 10)$ in GII. Abnormalities of the placenta and some gene expressions are thought to occur in SCNT and IVF pregnancies. These alterations were probably responsible for the production of oversized fetuses, which could result in high perinatal mortality (HIIL, 2014). Respiratory problems, weakness, and lack of appetite were the main clinical signs in this study.

In GI, $50 \%(5 / 10)$ of the calves were heavier than the mean birth weight for the breed (Table 1) based on MEIRELLES (2010). In GII, only one animal exhibited this feature. The mean birth weight was $43.03 \pm 14.72 \mathrm{~kg}$ in GI and 37.72 $\pm 6.33 \mathrm{~kg}$ in GII; however, the difference was not statistically significant. The cell lines used could also be responsible for producing oversized fetuses. In the present study, fibroblasts were used. There is a higher

Table 1 - Comparation of physical parameters from SCNT-derived calves (GI) and IVF-derived calves (GII).

\begin{tabular}{|c|c|c|}
\hline PHYSICAL PARAMETER & GI (\%) & GII (\%) \\
\hline & $\mathrm{n}=10$ & $\mathrm{n}=10$ \\
\hline Pale mucous membranes ${ }^{*}$ & $8 / 10(80 \%)^{a}$ & $2 / 10(20 \%)$ \\
\hline Pink mucous membranes ${ }^{*}$ & $2 / 10(20 \%)$ & $7 / 10(70 \%)^{b}$ \\
\hline Cyanotic mucous membranes ${ }^{*}$ & - & $1 / 10(10 \%)$ \\
\hline meconium-stained at birth $^{*}$ & $6 / 10(60 \%)$ & $2 / 10(20 \%)$ \\
\hline Suckling reflex $(\geq 20 \mathrm{~min})^{*}$ & $2 / 10(20 \%)$ & $6 / 10(60 \%)$ \\
\hline Sternal recumbency $(\geq 3 \mathrm{~min}){ }^{*}$ & - & - \\
\hline Lifetime $(>24$ Hours $){ }^{*}$ & $1 / 10(10 \%)^{\mathrm{a}}$ & $8 / 10(80 \%)$ \\
\hline Increased birthweight $(>45 \mathrm{Kg})^{\#}$ & $5 / 10(50 \%)$ & $1 / 10(10 \%)$ \\
\hline Flexural deformities ${ }^{*}$ & $3 / 10(30 \%)$ & - \\
\hline Oxygen therapy (intranasal catheter) ${ }^{*}$ & $6 / 10(60 \%)$ & $2 / 10(20 \%)$ \\
\hline
\end{tabular}

${ }^{*}$ Fisher exact test.

\# Non paired t-test.

${ }^{\text {a }}$ Clones different from IVF, $\mathrm{P}<0.05$.

${ }^{\mathrm{b}}$ IVF different from clones, $\mathrm{P}<0.05$. 
incidence of oversized fetuses in clones compared to that in in vitro-derived embryos, especially in clones produced from somatic cells compared with clones produced from embryonic cells (BERTOLINI \& ANDERSON, 2002; FARIN et al., 2006). Chromosomal abnormalities resulting from aberrant cell division can cause polyploidy in a variable proportion of the embryonic cells (SLIMANEBUREAU \& KING, 2002).

Increased body weight of animals derived from reproductive techniques is caused by aberrant in-utero energy metabolism resulting, for example, in hyperinsulinemia after birth (GARRY et al., 1996). In GII, the plasma insulin level was eight times higher than that in GI, which contrasted with previous research when half of the animals in GI were heavier than normal (Table 2). IVF calves possibly demonstrated insulin resistance at birth.

Because of temporary hypoxia at birth, hyperlactatemia is noted as a physiological condition (LESTER et al., 2014). When this situation is prolonged, more lactate is produced, and it becomes a marker of postnatal acid-base disturbances and may be a predictor of neonatal viability (BORRUTO et al., 2006). Moreover, there is a negative correlation between neonatal mortality and blood $\mathrm{pH}$, which indicates that metabolic acidosis leads to higher plasma lactate concentrations (BLEUL \& GOTZ, 2013). Hyperlactemia was noted in both groups during the experimental period. In GI, the plasma lactate level was higher than that in GII from the second hour of life (Table 2), which agrees with BORRUTO et al. (2006) because of the high mortality in GI. The animals in GII possibly had transitory physiological alterations that were compatible with ex utero adaptation.

In normal neonates, fetal structures of the heart, such as the ductus arteriosus and foramen ovale, close in the first few hours after birth (JAFARI \& HOSEINI, 2016; COFRÉ et al., 2017). These structures can persist and have been observed in cloned calves that died within a few days (GARRY et al., 1996). After birth, prolonged acidemia and hypoxic conditions may promote the maintenance of fetal circulation (patent foramen ovale and patent ductus arteriosus) (MEIRELES et al., 2010). Therefore, these events could contribute to hyperlactatemia in cloned calves.

Plasma glucose in newborn calves is 80 $120 \mathrm{mg} / \mathrm{dL}$ (SWENSON \& REECE, 1996). After birth, the umbilical cord is broken and maternal glucose is interrupted, which causes plasma hypoglycemia in newborns. This situation was observed immediately after birth in both groups (Table 2). The placenta

Table 2 - Moment (M), Number of animals (n), Mean ( $\bar{x}$ ) and Standard deviation (SD) for values of insulin, glucose, and lactate from SCNT-derived calves (GI) and IVF-derived calves (GII).

\begin{tabular}{|c|c|c|c|c|c|}
\hline & \multirow[t]{2}{*}{ Moment } & \multicolumn{2}{|c|}{---------------------------GI----------------------------- } & \multicolumn{2}{|c|}{----------------------------GII-----------------------. } \\
\hline & & $\mathrm{n}$ & $\bar{x} \pm \mathrm{SD}$ & $\mathrm{n}$ & $\bar{x} \pm \mathrm{SD}$ \\
\hline & $\mathrm{M}_{0}$ & 10 & $8.72 \pm 11.39 \mathrm{Ba}$ & 10 & $43.38 \pm 40.35 \mathrm{Aa}$ \\
\hline Insulin & $\mathrm{M}_{2}$ & 9 & $7.80 \pm 5.71 \mathrm{Ba}$ & 10 & $24.86 \pm 19.96 \mathrm{Aa}$ \\
\hline \multirow[t]{3}{*}{ (uU/mL) } & $\mathrm{M}_{12}$ & 7 & $38.04 \pm 28.63 \mathrm{a}$ & 8 & $44.91 \pm 32.57 \mathrm{a}$ \\
\hline & $\mathrm{M}_{0}$ & 10 & $30.70 \pm 11.97 \mathrm{~B}$ & 10 & $51.02 \pm 24.64 \mathrm{Aa}$ \\
\hline & $\mathrm{M}_{2}$ & 9 & $95.56 \pm 68.76 \mathrm{a}$ & 10 & $48.99 \pm 40.06 \mathrm{a}$ \\
\hline Glucose & $\mathrm{M}_{4}$ & 7 & $104.14 \pm 64.83 \mathrm{a}$ & 10 & $61.79 \pm 56.56 \mathrm{a}$ \\
\hline \multirow[t]{4}{*}{$(\mathrm{mg} / \mathrm{dL})$} & $\mathrm{M}_{6}$ & 7 & $133.00 \pm 87.17 \mathrm{a}$ & 8 & $84.29 \pm 70.69 \mathrm{a}$ \\
\hline & $\mathrm{M}_{12}$ & 7 & $101.43 \pm 48.92 \mathrm{a}$ & 8 & $92.64 \pm 80.22 \mathrm{a}$ \\
\hline & $\mathrm{M}_{0}$ & 10 & $11.02 \pm 3.20 \mathrm{a}$ & 10 & $8.59 \pm 3.96 \mathrm{a}$ \\
\hline & $\mathrm{M}_{2}$ & 9 & $14.65 \pm 6.64 \mathrm{Aa}$ & 10 & $5.80 \pm 5.07 \mathrm{Ba}$ \\
\hline Lactate & $\mathrm{M}_{4}$ & 7 & $11.20 \pm 5.16 \mathrm{Aa}$ & 9 & $4.95 \pm 1.69 \mathrm{Ba}$ \\
\hline \multirow[t]{2}{*}{$(\mathrm{mmol} / \mathrm{L})$} & $\mathrm{M}_{6}$ & 7 & $12.18 \pm 3.39 \mathrm{Aa}$ & 8 & $5.21 \pm 2.23 \mathrm{Ba}$ \\
\hline & $\mathrm{M}_{12}$ & 7 & $13.02 \pm 6.33 \mathrm{Aa}$ & 8 & $5.06 \pm 2.51 \mathrm{Ba}$ \\
\hline
\end{tabular}

${ }^{\text {Aa }}$ Mean values followed by different capital letters in the same row according to Tukey's Test or by different lowercase letters in the same column differ according to ANOVA $(\mathrm{P}<0.05)$. 
of cloned calves uses approximately $60 \%-75 \%$ of the maternal glucose (CHAVATTE-PALMER et al., 2012), and this may have contributed to the lower plasma glucose in GI after birth. Moreover, the situation observed in GI could be a result of fetal distress because of the rapid consumption of glycogen stores and the establishment of anaerobic glycolysis, which increases plasma lactate (ZACONETA, 2004).

In GI, three animals died before receiving colostrum. Of the remaining seven animals, six presented a weak suckling reflex and received colostrum via an esophageal tube. Therefore, the glucose concentration of these animals was measured with a portable glucometer starting $5 \mathrm{~h}$ after administration of colostrum (data not available). In these animals, the blood glucose concentration was lower than $50 \mathrm{mg} / \mathrm{dL}$. Thus, i.v. glucose was administered. Therefore, this procedure may contribute to the measurement of median values within the physiological patterns at $6 \mathrm{~h}$ of life (Table 2). However, at $12 \mathrm{~h}$, the plasma glucose level was lower than $50 \mathrm{mg} / \mathrm{dL}$. In GII, eight animals had a normal suckling reflex and ingested the colostrum offered normally; for this reason, blood glucose was not measured. However, at $6 \mathrm{~h}$, six of these animals were hypoglycemic even after ingesting colostrum.
These results confirmed that $80 \%$ of all calves available (12/15) were unable to maintain plasma glucose within the normal range even after ingesting colostrum. Hyperinsulinemia may be responsible for massive cell glucose entry, reducing plasma glucose levels.

According to EVERTS et al. (2008), SCNT placentomes have gene alterations that result in lower oxygen supply to the fetus, especially during the last trimester of pregnancy. Therefore, this situation contributed to fetal distress in utero resulting in meconium staining at birth, which was observed in $60 \%(6 / 10)$ of the GI animals and $20 \%(2 / 10)$ of the GII animals (Table 1), a situation that contributed to higher plasma lactate in GI.

The respiratory rate was not significantly different between the groups, but GII had higher values than those observed by FEITOSA \& BENESI (2014) (46 \pm 16 breaths/minute) for newborn Nellore calves (Table 3). However, the mean values for this group exhibited a decline, but with no statistical difference, tending to normalization concerning the findings for researchers at $2 \mathrm{~h}$. In GI, the respiratory rate at birth indicated bradypnea (FEITOSA \& BENESI, 2014). However, the mean values increased and exhibited tachypnea until the end of the experimental period.

Table 3 - Moment (M), Number of animals (n), Mean $(\bar{x})$ and Standard deviation (SD) for values of respiratory rate, heart rate and rectal temperature from SCNT-derived calves (GI) and IVF-derived calves (GII).

\begin{tabular}{|c|c|c|c|c|c|}
\hline & \multirow[t]{2}{*}{ Moment } & \multicolumn{2}{|c|}{------------------------GI----------------------- } & \multicolumn{2}{|c|}{-----------------------GII------------------- } \\
\hline & & $\mathrm{n}$ & $\bar{x} \pm \mathrm{SD}$ & $\mathrm{n}$ & $\bar{x} \pm \mathrm{SD}$ \\
\hline \multirow{5}{*}{$\begin{array}{l}\text { Respiratory Rate } \\
\text { (breaths/minute) }\end{array}$} & $\mathrm{M}_{0}$ & 10 & $39 \pm 22 b$ & 10 & $51 \pm 11$ \\
\hline & $\mathrm{M}_{2}$ & 9 & $55 \pm 6 \mathrm{Aab}$ & 10 & $42 \pm 10 \mathrm{~B}$ \\
\hline & $\mathrm{M}_{4}$ & 7 & $57 \pm 15 \mathrm{Aab}$ & 10 & $42 \pm 7 \mathrm{~B}$ \\
\hline & $\mathrm{M}_{6}$ & 7 & $56 \pm 15 \mathrm{ab}$ & 8 & $43 \pm 14$ \\
\hline & $\mathrm{M}_{12}$ & 7 & $68 \pm 16 \mathrm{Aa}$ & 8 & $42 \pm 4 \mathrm{~B}$ \\
\hline \multirow{5}{*}{$\begin{array}{l}\text { Heart Rate } \\
(\mathrm{bpm})\end{array}$} & $\mathrm{M}_{0}$ & 10 & $99 \pm 37$ & 10 & $127 \pm 44$ \\
\hline & $\mathrm{M}_{2}$ & 9 & $132 \pm 24$ & 10 & $137 \pm 25$ \\
\hline & $\mathrm{M}_{4}$ & 7 & $140 \pm 22$ & 10 & $137 \pm 24$ \\
\hline & $\mathrm{M}_{6}$ & 7 & $143 \pm 40$ & 8 & $127 \pm 21$ \\
\hline & $\mathrm{M}_{12}$ & 7 & $141 \pm 32$ & 8 & $136 \pm 19$ \\
\hline \multirow{5}{*}{$\begin{array}{l}\text { Rectal Temperature } \\
\left(\mathrm{C}^{\circ}\right)\end{array}$} & $\mathrm{M}_{0}$ & 10 & $39.22 \pm 0,65 \mathrm{a}$ & 10 & $38.84 \pm 0.78 \mathrm{a}$ \\
\hline & $\mathrm{M}_{2}$ & 9 & $37.23 \pm 0.87 \mathrm{~b}$ & 10 & $37.74 \pm 1.10 \mathrm{~b}$ \\
\hline & $\mathrm{M}_{4}$ & 7 & $37.87 \pm 1.00 \mathrm{~b}$ & 10 & $37.88 \pm 0.80 \mathrm{~b}$ \\
\hline & $\mathrm{M}_{6}$ & 7 & $38.17 \pm 1.16 \mathrm{~b}$ & 8 & $38.16 \pm 0.70 \mathrm{ab}$ \\
\hline & $\mathrm{M}_{12}$ & 7 & $38.03 \pm 1.10 \mathrm{~b}$ & 8 & $38.01 \pm 0.58 \mathrm{ab}$ \\
\hline
\end{tabular}

${ }^{\text {Aa }}$ Mean values followed by different capital letters in the same row according to Tukey's Test or by different lowercase letters in the same column differ according to ANOVA $(\mathrm{P}<0.05)$. 
According to the literature, approximately $90 \%$ of cloned calves have respiratory disturbances during the neonatal period (BRISVILLE et al., 2011). In this study, $89 \%(8 / 9)$ of GI animals underwent necropsy. All animals displayed pathological changes accompanying some respiratory tract segments, especially pulmonary edema associated with congestion and sometimes atelectasis. These pulmonary alterations were identified during the macroscopic evaluation and were probably associated with fetal distress and aspiration of meconium.

Clinically, animals with meconium aspiration had intense dyspnea associated with bradypnea after birth with subsequent tachypnea that persisted as long as they were alive, with a slow decrease during the evaluation period. The meconium prevents the incorporation of surfactant phospholipids into a stable monolayer, making breathing difficult. Moreover, vasoconstriction occurs, especially in the pulmonary artery, leading to pulmonary hypertension with reduced blood flow to the alveoli, resulting in hypoxia (BLEUL, 2009). In this study, 66.7\% (6/9) of the necropsied GI animals were born with meconium staining, and $83.3 \%(5 / 6)$ of these animals had atelectasis and pulmonary edema associated with meconium in the alveolar space that was observed upon microscopic examination. The other animals in this group, which were born with no meconium staining, did not exhibit these respiratory changes. Thus, it was probable that the clinical-pathological changes were caused by meconium aspiration.

Atelectasis could be caused by a surfactant deficiency or meconium aspiration (LESTER et al., 2014) with serious respiratory disturbances. It is important to emphasize that in previous studies, animals with surfactant deficiency or meconium aspiration had similar respiratory changes (BLEUL, 2009).

The Apgar score index can be used to assess neonatal viability immediately after birth (FEITOSA \& BENESI, 2014). In this study, a comparison of this index immediately after birth and at $5 \mathrm{~min}$ of life between the groups did not show a statistical difference $(\mathrm{P}>0.05)$. However, it was noted that low and moderate vitality affected $80 \%(8 / 10)$ and $90 \%(9 / 10)$ of GI and GII animals, respectively, after birth. At 5 min of life, the GII animals exhibited an improvement in vitality. The same situation was not observed in GI; the six animals that remained had low $(1 / 10)$ and moderate $(5 / 10)$ vitality and were subjected to oxygen therapy. However, this procedure did not contribute to an improvement in their respiratory status once the plasma lactate concentration remained immutable during all periods of this study for this group (Table 1). These observations in cloned calves attested to possible disturbances suffered by these animals in utero and more difficult adaptation to life ex utero.

Furthermore, the Apgar score index could be used to assess neonatal viability and predict early signs of peripartum asphyxia (LESTER et al., 2014). Thus, calves in GI possibly had early asphyxia.

A negative correlation was noted $(\mathrm{r}=-0.513$; $\mathrm{P}<0.05)$ between the Apgar score and plasma lactate concentration in both groups immediately after birth; thus, animals with low and moderate vitality evolved into metabolic acidosis. According to DUFTY \& SLOSS (1977), when this metabolic status was prolonged, lethargy, a weak or absent suckling reflex, and difficulty in maintaining sternal recumbency were noted. All these signs were observed in the GI animals.

GII had a minor mortality rate after birth. Therefore, it is possible that because of the normalization of the respiratory rate, plasma lactate concentration, and Apgar index score, these animals did not have difficulty in adapting to life ex utero.

Meconium-stained calves, which died a few hours after birth, presented bradycardia, which caused tissue oxygenation (NUNES, 2009). Bradycardia occurs when the heart rate is lower than 90 bpm (HOUSE \& GUNN, 2014). In this study, there was no statistical difference between groups and moments. However, $50 \%(5 / 10)$ of the GI animals had this feature after birth, and three were meconiumstained and died in the first $24 \mathrm{~h}$ of life. Bradycardia was noted in two animals in GII at birth; although, none were meconium-stained, and one died after 4 $\mathrm{h}$ of life.

Additionally, pale mucus in the eyes was observed in $80 \%(8 / 10)$ of the GI animals and probably corresponded to a large number of animals with low $(2 / 10)$ and moderate $(6 / 10)$ vitality in this group $(\mathrm{P}<0.05)$. Moreover, this coloration is a predictor of anemia. This pathologic situation is common in newborns diagnosed by laboratory techniques. However, pale mucus is not ordinary in such animals (SILVA, 2016). This author's values for mean hemoglobin $(11.36 \pm 0.46 \mathrm{~g} / \mathrm{dL})$, mean RBCs $\left(8.27 \pm 0.25 \times 10^{6} / \mathrm{mm}^{3}\right)$, and mean hematocrit (39.01 $\pm 1.73 \%$ ) for Nellore calves born delivered from the corticosteroid-induced cesarean section were higher than those observed in both groups in this study. House and Gunn (2014) showed that newborn calves with hemoglobin values less than $10 \mathrm{~g} / \mathrm{dL}$ could be considered anemic. The erythrogram showed mean hemoglobin values below the aforementioned values for GI during the experimental period (Table 4). 
Additionally, clinical signs of anemia were observed in eight animals in this group.

Hemolytic factors can be responsible for this disturbance in newborns (BATCHELDER et al., 2007). Hemolytic destruction of RBCs causes increases in total and indirect bilirubin concentrations, as noted for clones in this study, indicating that this was the possible cause of anemia (Table 5). Moreover, this fact was corroborated by the observation of bile pigments in the renal tubules in the microscopic analysis. Therefore, anemia also contributed to the respiratory changes and increased plasma lactate concentrations observed in GI.

Concomitantly, serum iron values for GI were within the physiological limits during the study (Table 5). Thus, these findings excluded the hypothesis that the anemia observed in GI was caused by iron deficiency, as reported by other authors (BIRGEL JÚNIOR et al.,2011). However, regarding minerals, the average calcium concentrations in GI were above the reference range for bovine species (KANEKO et al., 2008) indicating transient hypercalcemia, with values higher than those in GII during the first $6 \mathrm{~h}$ of life (Table 5).

In newborn foals, this situation was related to animals with perinatal asphyxia caused by placental dysfunction (McFARLANE, 2014). No similar reference was identified in the literature for newborn calves; however, the genesis of hypercalcemia in the animals in GI may be the same as those mentioned by the previous author. Under the conditions described above, the metabolic condition of the newborn

Table 4 - Moment (M), Number of animals (n), Median (Md), Mean ( $\bar{x}$ ) and Standard deviation (SD) for values of Total Red Blood Cells (RBC), Hemoglobin, Hematocrit, Mean Corpuscular Volume (MCV), Mean Corpuscular Hemoglobin concentration (MCHC) from SCNT-derived calves (GI) and IVF-derived calves (GII).

\begin{tabular}{|c|c|c|c|c|c|}
\hline & \multirow[t]{2}{*}{ Moment } & \multicolumn{2}{|c|}{----------------------------GI--------------------------- } & \multicolumn{2}{|c|}{ 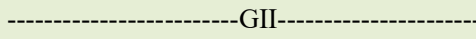 } \\
\hline & & $\mathrm{n}$ & $\bar{x} \pm \mathrm{SD}$ & $\mathrm{n}$ & $\bar{x} \pm \mathrm{SD}$ \\
\hline \multirow{5}{*}{$\mathrm{RBC}\left(\mathrm{x} 10^{6} / \mathrm{mm}^{3}\right)$} & $\mathrm{M}_{0}$ & 10 & $6.12 \pm 1.82 \mathrm{~b}$ & 10 & $7.46 \pm 1.66 \mathrm{a}$ \\
\hline & $\mathrm{M}_{2}$ & 9 & $6.67 \pm 1.92 \mathrm{ab}$ & 10 & $7.37 \pm 1.84 \mathrm{ab}$ \\
\hline & $\mathrm{M}_{4}$ & 7 & $6.91 \pm 1.86 \mathrm{a}$ & 10 & $7.26 \pm 1.80 \mathrm{ab}$ \\
\hline & $\mathrm{M}_{6}$ & 7 & $6.88 \pm 1.92 \mathrm{a}$ & 8 & $7.04 \pm 2.15 \mathrm{ab}$ \\
\hline & $\mathrm{M}_{12}$ & 7 & $6.58 \pm 2.02 \mathrm{ab}$ & 8 & $6.91 \pm 2.06 \mathrm{~b}$ \\
\hline \multirow{5}{*}{ Hemoglobin (g/dL) } & $\mathrm{M}_{0}$ & 10 & $8.17 \pm 2.69 b$ & 10 & $10.78 \pm 2.49 \mathrm{a}$ \\
\hline & $\mathrm{M}_{2}$ & 9 & $8.76 \pm 2.74 \mathrm{ab}$ & 10 & $10.60 \pm 2.36 \mathrm{a}$ \\
\hline & $\mathrm{M}_{4}$ & 7 & $9.41 \pm 2.58 \mathrm{a}$ & 10 & $10.65 \pm 2.23 \mathrm{a}$ \\
\hline & $\mathrm{M}_{6}$ & 7 & $9.43 \pm 2.63 \mathrm{a}$ & 8 & $10.15 \pm 2.63 \mathrm{ab}$ \\
\hline & $\mathrm{M}_{12}$ & 7 & $9.10 \pm 2.98 \mathrm{ab}$ & 8 & $9.81 \pm 2.56 \mathrm{~b}$ \\
\hline \multirow{5}{*}{ Hematocrit (\%) } & $\mathrm{M}_{0}$ & 10 & $26.63 \pm 8.55 \mathrm{~b}$ & 10 & $33.88 \pm 6.60 \mathrm{a}$ \\
\hline & $\mathrm{M}_{2}$ & 9 & $29.10 \pm 9.62 \mathrm{ab}$ & 10 & $33.81 \pm 7.29 \mathrm{a}$ \\
\hline & $\mathrm{M}_{4}$ & 7 & $31.20 \pm 8.55 \mathrm{a}$ & 10 & $33.50 \pm 7.02 \mathrm{ab}$ \\
\hline & $\mathrm{M}_{6}$ & 7 & $31.04 \pm 8.82 \mathrm{a}$ & 8 & $31.99 \pm 7.99 \mathrm{ab}$ \\
\hline & $\mathrm{M}_{12}$ & 7 & $29.87 \pm 8.60 \mathrm{ab}$ & 8 & $31.49 \pm 7.42 \mathrm{~b}$ \\
\hline \multirow{5}{*}{$\operatorname{MCV}\left(\mu^{3}\right)$} & $\mathrm{M}_{0}$ & 10 & $43.65 \pm 5.39$ & 10 & $45.76 \pm 3.75$ \\
\hline & $\mathrm{M}_{2}$ & 9 & $43.43 \pm 5.38$ & 10 & $46.33 \pm 3.55$ \\
\hline & $\mathrm{M}_{4}$ & 7 & $45.19 \pm 3.42$ & 10 & $46.54 \pm 4.04$ \\
\hline & $\mathrm{M}_{6}$ & 7 & $45.03 \pm 3.79$ & 8 & $46.09 \pm 4.08$ \\
\hline & $\mathrm{M}_{12}$ & 7 & $45.17 \pm 4.33$ & 8 & $42.97 \pm 7.73$ \\
\hline \multirow{5}{*}{$\mathrm{MCHC}(\mathrm{g} / \mathrm{dL})$} & $\mathrm{M}_{0}$ & 10 & $30.61 \pm 1.62$ & 10 & $31.60 \pm 1.95$ \\
\hline & $\mathrm{M}_{2}$ & 9 & $30.26 \pm 1.63$ & 10 & $30.65 \pm 2.25$ \\
\hline & $\mathrm{M}_{4}$ & 7 & $30.17 \pm 1.72$ & 10 & $30.67 \pm 3.55$ \\
\hline & $\mathrm{M}_{6}$ & 7 & $30.43 \pm 1.45$ & 8 & $31.71 \pm 2.43$ \\
\hline & $\mathrm{M}_{12}$ & 7 & $30.16 \pm 0.96$ & 8 & $31.02 \pm 2, .07$ \\
\hline
\end{tabular}

${ }^{\text {Aa }}$ Mean values followed by different capital letters in the same row according to Tukey's Test or by different lowercase letters in the same column differ according to ANOVA $(\mathrm{P}<0.05)$. 
Table 5 - Moment (M), Number of animals (n), Mean $(\bar{x})$ and Standard deviation (SD) for values of Indirect Bilirubin (I.B.), Total Bilirubin (T.B.), Direct Bilirubin (D.B.), Calcium, Iron and Ionized Calcium from SCNT-derived calves (GI) and IVF-derived calves (GII).

\begin{tabular}{|c|c|c|c|c|c|}
\hline & \multirow[t]{2}{*}{ Moment } & \multicolumn{2}{|c|}{----------------------GI-------------------------' } & \multicolumn{2}{|c|}{ 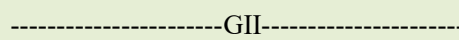 } \\
\hline & & $\mathrm{n}$ & $\bar{x} \pm \mathrm{SD}$ & $\mathrm{n}$ & $\bar{x} \pm \mathrm{SD}$ \\
\hline & $\mathrm{M}_{0}$ & 10 & $0.64 \pm 0.49 \mathrm{Aa}$ & 10 & $0.15 \pm 0.13 \mathrm{Ba}$ \\
\hline & $\mathrm{M}_{2}$ & 9 & $1.23 \pm 1.03 \mathrm{Aa}$ & 10 & $0.27 \pm 0.17 \mathrm{Ba}$ \\
\hline I.B. & $\mathrm{M}_{4}$ & 7 & $1.18 \pm 0.83 \mathrm{Aa}$ & 10 & $0.23 \pm 0.21 \mathrm{Ba}$ \\
\hline \multirow[t]{4}{*}{$(\mathrm{mg} / \mathrm{dL})$} & $\mathrm{M}_{6}$ & 7 & $1.40 \pm 0.97 \mathrm{Aa}$ & 8 & $0.26 \pm 0.25 \mathrm{Ba}$ \\
\hline & $\mathrm{M}_{12}$ & 7 & $1.32 \pm 1.07 \mathrm{Aa}$ & 8 & $0.16 \pm 0.11 \mathrm{Aa}$ \\
\hline & $\mathrm{M}_{0}$ & 10 & $1.07 \pm 0.76 \mathrm{Aa}$ & 10 & $0.38 \pm 0.16 \mathrm{Ba}$ \\
\hline & $\mathrm{M}_{2}$ & 9 & $1.37 \pm 0.66 \mathrm{Aa}$ & 10 & $0.46 \pm 0.19 \mathrm{Ba}$ \\
\hline T.B. & $\mathrm{M}_{4}$ & 7 & $1.26 \pm 1.13 \mathrm{Aa}$ & 10 & $0.44 \pm 0.21 \mathrm{Aa}$ \\
\hline \multirow[t]{4}{*}{$(\mathrm{mg} / \mathrm{dL})$} & $\mathrm{M}_{6}$ & 7 & $1.66 \pm 0.97 \mathrm{Aa}$ & 8 & $0.51 \pm 0.23 \mathrm{Aa}$ \\
\hline & $\mathrm{M}_{12}$ & 7 & $1.56 \pm 1.30 \mathrm{Aa}$ & 8 & $0.44 \pm 0.23 \mathrm{Aa}$ \\
\hline & $\mathrm{M}_{0}$ & 10 & $0.38 \pm 0.2 \mathrm{Aa}$ & 10 & $0.23 \pm 0.15 \mathrm{Ba}$ \\
\hline & $\mathrm{M}_{2}$ & 9 & $0.47 \pm 0.26 \mathrm{Aa}$ & 10 & $0.19 \pm 0.08 \mathrm{Ba}$ \\
\hline D.B. & $\mathrm{M}_{4}$ & 7 & $0.28 \pm 0.17 \mathrm{Aa}$ & 10 & $0.21 \pm 0.08 \mathrm{Aa}$ \\
\hline \multirow[t]{2}{*}{$(\mathrm{mg} / \mathrm{dL})$} & $\mathrm{M}_{6}$ & 7 & $0.56 \pm 0.38 \mathrm{Aa}$ & 8 & $0.26 \pm 0.08 \mathrm{Aa}$ \\
\hline & $\mathrm{M}_{12}$ & 7 & $0.68 \pm 0.63 \mathrm{Aa}$ & 8 & $0.31 \pm 0.09 \mathrm{Aa}$ \\
\hline \multirow{5}{*}{$\begin{array}{l}\text { Calcium } \\
(\mathrm{mg} / \mathrm{dL})\end{array}$} & $\mathrm{M}_{0}$ & 10 & $15.74 \pm 3.09 \mathrm{~A}$ & 10 & $11.73 \pm 2.62 \mathrm{~B}$ \\
\hline & $\mathrm{M}_{2}$ & 9 & $15.8 \pm 3.42 \mathrm{~A}$ & 10 & $12.56 \pm 3.09 \mathrm{~B}$ \\
\hline & $\mathrm{M}_{4}$ & 7 & $14.14 \pm 1.93 \mathrm{~A}$ & 10 & $10.82 \pm 2.79 \mathrm{~B}$ \\
\hline & $\mathrm{M}_{6}$ & 7 & $15.28 \pm 3.69 \mathrm{~A}$ & 8 & $10.27 \pm 2.80 \mathrm{~B}$ \\
\hline & $\mathrm{M}_{12}$ & 7 & $13.67 \pm 4.06$ & 8 & $10.44 \pm 3.11$ \\
\hline \multirow{5}{*}{$\begin{array}{l}\text { Iron } \\
(\mu \mathrm{g} / \mathrm{dL})\end{array}$} & $\mathrm{M}_{0}$ & 10 & $64.72 \pm 33,24$ & 10 & $53.71 \pm 14.53 \mathrm{a}$ \\
\hline & $\mathrm{M}_{2}$ & 9 & $77.10 \pm 45,35$ & 10 & $52.60 \pm 16.24 \mathrm{a}$ \\
\hline & $\mathrm{M}_{4}$ & 7 & $79.66 \pm 43,92 \mathrm{~A}$ & 10 & $43.52 \pm 15.00 \mathrm{Bab}$ \\
\hline & $\mathrm{M}_{6}$ & 7 & $66.83 \pm 28,88 \mathrm{~A}$ & 8 & $38.56 \pm 15.73 \mathrm{Bb}$ \\
\hline & $\mathrm{M}_{12}$ & 7 & $80.60 \pm 44,14 \mathrm{~A}$ & 8 & $33.43 \pm 19.23 \mathrm{Bb}$ \\
\hline \multirow{5}{*}{$\begin{array}{l}\text { Ionized calcium } \\
(\mathrm{mg} / \mathrm{dL})\end{array}$} & $\mathrm{M}_{0}$ & 10 & $10.64 \pm 1.95 \mathrm{~A}$ & 10 & $8.18 \pm 1.76 \mathrm{~B}$ \\
\hline & $\mathrm{M}_{2}$ & 9 & $10.39 \pm 2.04 \mathrm{~A}$ & 10 & $8.42 \pm 1.86 \mathrm{~B}$ \\
\hline & $\mathrm{M}_{4}$ & 7 & $9.30 \pm 1.32$ & 10 & $7.72 \pm 2.09$ \\
\hline & $\mathrm{M}_{6}$ & 7 & $9.96 \pm 2.40 \mathrm{~A}$ & 8 & $7.02 \pm 1.98 \mathrm{~B}$ \\
\hline & $\mathrm{M}_{12}$ & 7 & $8.93 \pm 2.56$ & 8 & $7.39 \pm 2.20$ \\
\hline
\end{tabular}

${ }^{\text {Aa }}$ Mean values followed by different capital letters in the same row according to Tukey's Test or by different lowercase letters in the same column differ according to ANOVA $(\mathrm{P}<0.05)$.

resulted in acidosis. Thus, low $\mathrm{pH}$ caused calcium to detach from albumin, increasing serum concentrations of ionized calcium (KANEKO et al., 2008). This observation was identified in both groups; however, it was quantitatively higher in GI (Table 5).

\section{CONCLUSION}

It was concluded that IVF animals had higher survival during the evaluation period because of greater adaptation to the extra uterine environment. The high postpartum mortality in the cloned animals was related to issues associated with fetal distress.

\section{ACKNOWLEDGEMENTS}

The authors would like to thank the Laboratory of Animal Reproduction FertVitro and the Veterinary Clinical Laboratory TecnolabVet for the laboratory analysis. And was financed in part by the Coordenação de Aperfeiçoamento de Pessoal de Nível Superior (CAPES), Brasil - Finance code 001.

\section{BIOETHICS AND BIOSECURITY COMMITTEE APPROVAL}

The experimental protocol was approved by the Ethics Principles of Animal Experimentation of the Faculdade de

Ciência Rural, v.51, n.7, 2021. 
Medicina Veterinária de Araçatuba (UNESP/FMVA) under process number 2014-01354.

\section{DECLARATION OF CONFLICT OF INTEREST}

The authors declare no conflict of interest. The founding sponsors had no role in the design of the study; in the collection, analyses, or interpretation of data; in the writing of the manuscript, and in the decision to publish the results.

\section{AUTHORS' CONTRIBUTIONS}

All authors contributed equally to the manuscript.

\section{REFERENCES}

BAIRD, A.N. Bovine Urogenital Surgery In. HENDRICKSON, D.A.; BAIRD, A.N. Turner and McIlwraith's Techniques in Large Animal Surgery. 4th Ed. Wiley, Hoboken, New Jersey, 2013, p.252-265.

BERTOLINI, M.; ANDERSON, G.B. The placenta as a contributor to production of large calves. Theriogenology. v.57, n.1, p.181187, 2002. Available from: <https://doi.org/10.1016/S0093691X(01)00665-3>. Accessed: May, 19, 2018. doi: 10.1016/ S0093-691X(01)00665-3.

BIRGEL JUNIOR, E.H., et al. Clinical disorders observed during the first 30 days of life of cloned Zebu calf. Acta Scientiae Veterinariae. v.39(Suppl 1): p. $243-252,2011$. Available from: Available from: <http://www.ufrgs.br/actavet/39-suple-1/30\%20 Supl_s243-s252.pdf>. Accessed: Jul. 20, 2016.

BLEUL, U. Respiratory distress syndrome in calves. Veterinary Clinics of North America: Food animal practice v.25, n.1, p.179-193,2009. Available from: <https://doi.org/10.1016/j.cvfa.2008.10.002> Accessed: Dec. 20, 2017. doi: 10.1016/j.cvfa.2008.10.002.

BLEUL, U; GÖTZ, E. The effect of lactic acidosis on the generation and compensation of mixed respiratory-metabolic acidosis in neonatal calves. Veterinary Record. v.172, n.20, p.528-532, 2013. Available from: <http://dx.doi.org/10.1136/vr.101192>. Accessed: Jan. 6, 2020. doi: 10.1136/vr.101192.

BORRUTO, F. et al. Screening of fetal distress by assessment of umbilical cord lactate. Clinical and Experimental Obstetrics Gynecology. v.33, n.4, p.219-222, 2006. Available from: $<$ https:// europepmc.org/abstract/med/17211969>. Accessed: Oct. 27, 2018.

BRISVILLE, A.C., et al., Respiratory disease in neonatal cloned calves. Journal Veterinary Internal Medicine. v. 25, n. 2, p.373379, 2011. Available from: <https://onlinelibrary.wiley.com/doi/ epdf/10.1111/j.1939-1676.2011.0693.x>. Accessed: Jul. 10, 2015. doi: 10.1111/j.1939-1676.2011.0693.x.

CHAVATTE-PALMER, P. et al. Review: Placental perturbations induce the developmental abnormalities often observed in bovine somatic cell nuclear transfer. Placenta 33(Suppl.): p.99-104, 2012. Available from: <https://doi.org/10.1016/j.placenta.2011.09.012>. Accessed: Jul. 19, 2019. doi: 10.1016/j.placenta.2011.09.012.

COFRÉ, S. et al. A case of complete resealing of patent foramen ovale in a cloned red angus calf. Journal of Stem Cell Research and
Transplantation. v.4. n.1, p.1027, 2017. Available from: <https:// austinpublishinggroup.com/stemcell-research-transplantation/ fulltext/jscrt-v4-id1027.php>. Accessed: Aug. 29, 2020.

DUFTY, J. H., SLOSS, V. Anoxia in the bovine foetus. Australian Veterinary Journal. v.53, n.6, p.262-267, 1977. Available from: $<$ https://doi.org/10.1111/j.1751-0813.1977.tb00211.x>. Accessed: Jan. 25, 2018. doi: 10.1111/J.1751-0813.1977 TB00211.X.

EVERTS, R.E. et al. Aberrant gene expression patterns in placentomes is associated with phenotypically normal and abnormal cattle cloned by somatic cell nuclear transfer. Physiology Genomics. v.33, p.65-77, 2008. Available from <https://journals.physiology. org/doi/pdf/10.1152/physiolgenomics.00223.2007>. Accessed: May, 25, 2019. doi: 10.1152/physiolgenomics.00223.2007.

FEITOSA F.L.F.; BENESI F.J. 2014. Semiologia de recémnascidos ruminantes e equídeos, p.69-97. In: Feitosa F.L.F. (Ed.), Semiologia Veterinária: a arte do diagnóstico. $3^{\mathrm{a}} \mathrm{ed}$. Roca, São Paulo.

HILL, J.R. Incidence of abnormal offspring from cloning and other assisted reproductive technologies. Annual Review of Animal Bioscience, n.16, v.2, p.1-15, 2014. Available from: $<$ https://doi. org/10.1146/annurev-animal-022513-114109>. Accessed: Jun. 20, 2019. doi: 10.1146/annurev-animal-022513-114109.

HOUSE, J.K.; GUNN, A. A. Manifestation and management of disease in neonatal ruminants. In: SMITH, B. P. Large animal internal medicine 4th Ed. Mosby, St. Louis, 2014. p.333-366.

KANEKO, J. J. et al. Clinical biochemistry of domestic animals 6. ed. San Diego: Academic Press, 2008. p. 529-559.

JAFARI, D.A.; HOSEINI, F. Patent ductus arteriosus in a lamb: A case report. Veterinary Research Forum. v.7, n.1. p.85-88. 2016. Available from: <https://www.ncbi.nlm.nih.gov/pmc/articles/ PMC4867043/pdf/vrf-7-085.pdf >. Accessed: Aug. 30, 2020.

LESTER, G.D. et al. Perinatal adaptation, asphyxia and ressucitation. In: SMITH, B. P. Large animal internal medicine, 4th Ed. Mosby, St. Louis, 2014, p.252-261.

McFARLANE, D. Endocrine and metabolic disease In: SMITH, B. P. Large animal internal medicine 4th Ed. Mosby, St. Louis, 2014, p. 1339- 1387.

MEIRELLES, F. V. et al. Delivery of cloned offspring: experience in Zebu cattle (Bos indicus). Reproduction, Fertility and Development, v.22, n.1, p.88-97, 2010. Available from: <https:// doi.org/10.1071/RD09229>. Accessed: Feb. 21, 2016. doi:10.1071/ RD09229.

NUNES, M. T. O uso da cardiotocografia como método de diagnóstico da ocorrência de sofrimento fetal (hipóxia fetal) durante a vida intra-uterina de fetos da raça Nelore originados por meio da técnica de transferência nuclear de células somáticas adultas - Clonagem. 2009. 112f. Dissertação (Mestrado em Medicina Veterinária)- Curso de pós-graduação em Medicina Veterinária, Universidade de São Paulo.

SLIMANE-BUREAU, W.C., KING, W.A. Chromosomal abnormalities: a potential quality issue for cloned cattle embryos. Cloning Stem Cells 2002, v.4, n.4, p.319-329, 2002. Avalible from: < https://doi.org/10.1089/153623002321024998> Accessed: Nov. 29, 2020. doi: 10.1089/153623002321024998.

Ciência Rural, v.51, n.7, 2021. 
SILVA, L.R. Influência do tipo de nascimento (parto espontâneo, parto cesariana sem indução e com indução) no eritrograma de bezerros Nelore. 2016. 61f. Dissertação (Mestrado em Medicina Veterinária)- Curso de pós-graduação em Medicina Veterinária, Universidade de São Paulo.

SWENSON, M. J.; REECE, W. O. Dukes fisiologia dos animais domésticos. 11. ed. Rio de Janeiro: Guanabara Koogan, 1996.

THRALL, M.A, Hematologia e Bioquímica clínica veterinária. São Paulo: Roca, 2007. 582p.
WILMUT, I. et al. Viable offspring derived from fetal and adult mammalian cells. Nature, v.385, p.810-813. 1997. Available from: $<$ https://doi.org/10.1038/385810a0> Accessed: Jan. 21, 2019. doi: 10.1038/385810a0.

ZACONETA, C.A.M. Asfixia perinatal. In: MARGOTTO, P.R. Assistência ao recém-nascido de risco. Brasília. Pórfiro, 2004, p.383-391.

ZAR, J.H. Biostatistical analysis. 4. ed. New Jersey: PrenticeHall, 1999. $663 \mathrm{p}$ 